\title{
Gambaran Pengetahuan Keluarga Tentang Penanganan Pre-Hospital Pada Pasien Stroke di RSUD Kota Mataram
}

\author{
Siti Zuraida Muhsinin ${ }^{1 *} \&$ Baiq Melinda Firda Rukandani ${ }^{1}$ \\ ${ }^{1}$ Jurusan Ilmu Keperawatan, Universitas Nahdlatul Wathan Mataram \\ *Email : zuraidamuhsinin@gmail.com
}

\begin{abstract}
Abstrak : Stroke merupakan penyebab kematian dan kecacatan utama di Indonesia. Menurut data dari Riset Kesehatan Dasar (Riskesdas) tahun 2018 ditemukan prevalensi stroke di Indonesia sebesar 10,9 per 1.000 penduduk. Stroke saat ini harus dipandang sebagai kedaruratan medis selain serangan jantung. Keterlambatan untuk mendapatkan pertolongan medis dapat meningkatkan jumlah kematian dan kecacatan (Morton, Fontaine, Hudak \& Gallo, 2012). Tujuan penelitian ini adalah untuk mengidentifikasi pengetahuan keluarga tentang penanganan pre-hospital pada pasien stroke di RSUD Kota Mataram. Jenis penelitian ini adalah penelitian deskriptif yang mencoba mendeskripsikan atau menggambarkan pengetahuan keluarga tentang penanganan prehospital pada pasien stroke. Jumlah sampel dalam penelitian ini 33 orang diambil dengan teknik consecutive sampling, instrument yang digunakan untuk pengumpulan data adalah kuesioner. Hasil penelitian ini menujukkan pengetahuan keluarga tentang penanganan pre-hospital sebanyak 5 responden (15\%) pada kategori baik, sebanyak 12 responden (36\%) pada kategori cukup, dan sebanyak 16 responden (48\%) pada kategori kurang. Ketidaktauan keluarga tentang penanganan stroke dapat disebabkan kurangnya informasi yang didapatkan baik dari petugas kesehatan maupun dari media informasi lainnya.
\end{abstract}

Kata kunci: Pengetahuan Keluarga, Penanganan Pre-hospital, Stroke

\section{Pendahuluan}

Stroke adalah kerusakan otak akibat gangguan suplai darah yang dapat mengakibatkan seseorang sulit berjalan, berbicara, memahami serta kelumpuhan serta mati rasa pada anggota tubuh, stroke merupakan salah satu masalah kesehatan utama dan menjadi penyebab kematian ketiga di dunia setelah penyakit jantung coroner dan kanker (America Heart Associantion, 2015).

Penyakit stroke baik istemik maupun hemoragik dapat menimbulkan dampak terhadap penderitanya, dampak tersebut berupa gangguan fungsi motorik, sensorik, kognitif dan komunikasi baik secara singular atau pun kombinasi (Williams, Perry \& Watkins,2010). Stroke disebut juga brain attack atau serangan otak yang selalu terjadi secara tiba-tiba dengan berbagai macam gejala.

Stroke merupakan penyebab kematian dan kecacatan utama di Indonesia.Menurut data dari Riset Kesehatan Dasar (Riskesdas) tahun 2018 ditemukan prevalensi stroke di Indonesia sebesar 10,9 per 1.000 penduduk.

Stroke saat ini harus dipandang sebagai kedaruratan medis selain serangan jantung.Keterlambatan untuk mendapatkan pertolongan medis dapat meningkatkan jumlah kematian dan kecacatan (Morton, Fontaine, Hudak \& Gallo, 2012). Data World Health Organization (WHO) tahun 2016 menunjukan bahwa stroke membunuh satu orang setiap enam detik didunia. Dengan perkiraan setiap tahun 15 juta orang menderita stroke dimana lima juta penderita mengalami kematian dan lima juta penderita stroke lainnya mengalami kecacatan (World Health Organization, 2018).

Besarnya angka kejadian, kematian dan kecacatan akibat stroke secara signifikan meningkatkan beban penyakit dan dikeluarkan serta meningkatkan beban kelurga. Salah satu upaya yang dilakukan untuk menurunkan beban akibat penyakit stroke adalah meningkatkan outcome dengan memberikan tindakan/ penanganan terhadap kejadian stroke sekitar 83,9\% disebabkan oleh keterlambatan pra rumah sakit (Fassbender, Balucani, Walter, Levine, \& Haass,2013).

Penelitian Rachmawati, Andarini dan Ningsih (2017) dan Allo (2015) menyebutkan bahwa sebagian keluarga pasien stroke mempunyai pengetahuan yang kurang tentang resiko dan peringatan gejala stroke yang dapat menyebabkan keluarga tidak segera membawa pasien ke rumah sakit atau instalasi gawat darurat. Apabila seseorang tersebut mempunyai pengetahuan yang baik tentang faktor risiko dan peringatan gejala stroke maka seseorang tersebut akan menggunakan pengetahuannya sebagai dasar terbentuknya tindakan dengan segerah menghubungi layanan kegawat daruratan untuk mendapatkan pertolongan dengan segera.

Berdasarkan beberapa penjelasan diatas,maka dianggap perlu untuk dilakukan penelitian guna mengetahui bagaimana gambaran pengetahuan keluarga tentang penanganan prehospital pada pasien stroke. 


\section{Metode Penelitian}

Jenis penelitian ini adalah penelitian deskriptif yang mencoba mendeskripsikan/ menggambarkan pengetahuan keluarga tentang penanganan pre-hospital pada pasien stroke. Jumlah sampel dalam penelitian ini 33 orang diambil dengan teknik consecutive sampling, instrument yang digunakan untuk pengumpulan data adalah kuesioner

\section{Hasil dan Pembahasan}

\section{Hasil}

Setelah dilakukan penelitian didapatkan hasil :

Tabel Pengetahuan keluarga penanganan prehospital pada pasien stroke

\begin{tabular}{|c|c|c|}
\hline Kategori & Jumlah & Presentasi \\
\hline Baik & 5 & $15 \%$ \\
\hline Cukup & 12 & $36 \%$ \\
\hline Kurang & 16 & $48 \%$ \\
\hline Jumlah & $\mathbf{3 3}$ & $\mathbf{1 0 0}$ \\
\hline
\end{tabular}

Berdasarkan tabel diatas pengetahuan keluarga tentang penanganan pre-hospital pada pasien stroke di RSUD Kota Mataram menunjukkan bahwa sebanyak 5 responden (15\%) baik, sebanyak 12 responden (36\%) cukup, dan sebanyak 16 responden (48\%) kurang.

\section{Pembahasan}

Berdasarkan hasil penelitian dapat digambarankan sebagian besar pengetahuan keluarga tentang penanganan pre-hospital pada pasien stroke dalam kategori kurang (48\%).

Menurut penelitian yang dilakukan oleh Rahmina seseorang yang mempunyai pengetahuan kurang tentang faktor risiko, peringatan, dan ketidakpahaman tentang konsep time is brain akan terlambat dalam merespon stroke sebagai kondisi gawat darurat yang harus memerlukan penanganan segera sehingga semakin memperlambat kedatangan ke rumah sakit/ mencari bantuan kesehatan. Kurang nya pengetahuan dapat dipengaruhi oleh kurang nya sumber informasi yang diterima oleh keluarga tentang stroke. Informasi tentang penanganan pre-hospitalpasien stroke bisa didapatkan dari tenaga kesehatan, media sosial, maupun media masa.

Pengenalan tentang penanganan pre-hospital stroke pada keluarga perlu dikembangkan di Indonesia. Penelitian yang dilakukan Rahmina menyatakan bahwa seseorang yang mempunyai pengetahuan kurang akan terlambat dalam merespon stroke sebagai kondisi gawat darurat yang harus memelurkan penanganan segera sehingga semakin memperlambat kedatangan kerumah sakit/ mencari bantuan tenaga kesehatan. Kurangnya penanganan awal dapat dilihat dari keluarga yang tidak dapat mengidetifikasikan metode FAST. FAST merupakan singkatan dari face, Arms, Speech, Time. Keluarga dan masyarakat diharapkan memiliki pengetahuan yang baik tentang FAST yakni dapat menilai pasien dari ketidaksimetrisan wajah, kelumpuhan anggota gerak serta ketidak mampuan berbicara. Bila didapatkan kelainan maka keluarga memiliki kesadaran untuk segera membawa pasien ke rumah sakit.

\section{Kesimpulan}

Dari hasil penelitian Gambaran Pengetahuan Keluarga Tentang Penanganan Pre-hospital pada pasien stroke Di RSUD Kota Mataram didapatkan kategori terbanyak yaitu kurang sebanyak 16 responden (48\%) sedangkan yang cukup sebanyak 12 responden $(36 \%)$ dan baik sebanyak 5 responden (15\%).

\section{Daftar Pustaka}

America Heart Associantion, (2015).Fokus Utama Pembaruan Pendoman AHA 2015 untuk CPR dan ECC.Circulatoin.

Amelia, A. (2013). Hubungan Pengetahuan Keluarga Tentang Penyakit Stroke Dengan Dukungan Keluarga Dalam Merawat Pasien Stroke

Ainun Na'im dkk. (2019) Hubungan Tingkat Pengetahuan Keluarga Tentang Penyakit Stroke Dengan Penangananpre-hospital.

Batubara S., Tat F. Hubungan Antara Penanganan Awal dan Kerusakan Neurologis Pasien Stroke di RSUD Kupang. J Keperawatan Soedirman (2015).

Depkes NTB( 2012), Angka Pasien Stroke

Irdawati (2012).Hubungan Antara Pengetahuan Dan Sikap Keluarga Dengan Perilaku Pasca Stroke.

Irfan, M (2012). Fisioterapi Bagi Insan Stroke Edisi 1. Yogyakarta: Graha Ilmu

Handayani F. Pengetahuan Tentang Stroke, Faktor risiko, Tanda peringatan stroke dan Respon Mencari Bantuan Pada Pasien Stroke Iskemik, semarang : proceeding 2019.

Kementerian Kesehatan Republik Indonesia, Stroke (2018)

Marina T. N Rosmary, Fitria Handayani. (2020) Hubugan Pengetahuan Keluarga dan Perilaku Keluarga pada Penanganan Awal Kejadian Stroke.

Muswanti IJ. Hubungan Pengetahuan dan Sikap Dengan Perilaku Pencegahan Komplikasi Stroke Pada Penderita Hipertensi.

Nursalam (2016). Metodologi Penelitian Ilmu Keperawatan. Jakarta: Salemba Medika 
Rachmawati, D., Andarini, S., \& Ningsih, D. K. (2017) Pengetahuan keluarga berperan terhadap keterlambatan kedatangan pasien stroke iskemik akut di instalasi gawat darurat. Jurnal Kedokteran Brawijaya.

Ratnawardani, Wasito \& Safitri.(2018) Pengalaman keluarga dalam penanganan serangan pertama pada pasien stroke.

Rasyid, AFS. Hubungan tingkat pengetahuan stroke dan tigkat pendidikan pada keluarga pasien stroke dengan tindakan keluarga pada penanganan awal stroke akut di RSPAD Gatot Soebroto Jakarta Januari- Februari 2013.

Riset Kesehatan Dasar (2018). Kecendrungan Prevalensi Stroke

Sastroasmoro, Sudigdo \& Ismael, Sofyan. 2014. Dasar - Dasar Metodologi Penelitian Klinis Edisi ke-5. Jakarta : Sagung Seto.

Semet, Prof R D GR. Kembuan MAHN, Karema W. Gambaran pengetahuan stroke pada penderita dan keluarga. 2016.

Siti kurniasih dkk.(2020) Gambaran Pengetahuan Keluarga Tentang Perawatan Pasien Stroke.

Wulandari, T. (2019).Rasio Neutrofil Limfosit Sebagai Prediktor Tingkat Keparahan Stroke Iskemik. Jurnal Ilmiah Kesehatan Sandi Husada. 